\title{
MAIN POLITICAL AND ECONOMIC EVENTS OF NOVEMBER 2015
}

\author{
S.Zhavoronkov
}

The shooting down of a Russian bomber by a Turkish warplane at the TurkeySyria border has led to a sharp increase in international tensions. Russia has slammed Turkey with economic sanctions, which can likewise be damaging to the Russian economy because of Russia's huge trade surplus with Turkey. The quest for a political compromise that may bring an end to hostilities is Syria has so far been slower than expected.

The main event of November 2015 was the acute escalation of the crisis in the Middle East caused by the shooting down of a Russian bomber by a Turkish warplane over the northwestern sector of the Turkey-Syria border. According to the Russian side, the bomber was destroyed while being in Syrian airspace, whereas the Turkish side has claimed that it was hit after having violated Turkish airspace. Two persons lost their lives in that incident - one of the twocrew members of the Russian airplane, and one member of the rescue team sent to look for the two men. Russia demanded an apology and compensation from Turkey. Turkey responded by stating that it had merely implemented the right of self-defence, although, formally, Turkish President Tayyip Erdogan said in an interview that he was saddened by the Russian jet's downing and that Turkey would have acted differently if it had known that the warplane was Russian. The Russian side, in its turn, justly pointed out that even if the plane had really strayed into Turkish airspace, Turkey should not have resorted to the use of lethal force. The reason for the escalation in violence is quite clear: Russia airplanes were bombing the area populated by Syrian Turkmen (also referred to as Syrian Turkoman), widely believed in Turkey to be pure Turks. Most of the Syrian Turkoman resolutely oppose President Bashar al-Assad' regime. Apparently, the Turkish government decided that Turkey was strong enough to challenge Russia. On the whole, the governments of NATO countries have accepted the Turkish version of events, although they expressed their views. Thus, President Barak Obama expressed regret over the incident with the Russian warplane. The Russian authorities characterized Turkey's actions as de facto protection and accused Turkey of being a purchaser of oil extracted by IS. In his turn, Erdogan categorically rejected these allegations as false and accused Bashar al-Assad of buying a great deal of IS oil. It should be noted that in between the oil-rich provinces of eastern Syria and the Turkish border there lies an area controlled by Kurdish militias. Apparently, some amount of oil is indeed being smuggled across the Syria-Turkey border, though it is very difficult to pinpoint the organizers of this illegal trade: in war-torn Syria, anybody can play the role of primary or secondary sellers of oil. However absurd it might seem, even belligerent parties may trade with each other due to corrupt deals between their respective field commanders.

The aforesaid events dashed chances of a diplomatic resolution of the Syrian crisis, at least for the time being. The hopes of reaching a breakthrough had emerged in the aftermath of the 14 November terror attacks in Paris that claimed more than two hundred lives, and RF President Putin's admission, on 
17 November, that the crash of the Russian airbus in the Sinai 'was a terror act'. Terrorist groups affiliated to 'Islamic State' claimed responsibility for both the Paris attacks and for the downing of the Russian passenger plane. There were expectations that a number of states, including Russia, would join forces to combat terrorism, and much hope was pinned on Vladimir Putin's meetings with President Francois Hollande of France and US President Barack Obama. Also, there were expectations of a breakthrough at the second round of the multinational Vienna talks on Syria. It should be mentioned that at the first of Vienna talks, held in late October, the conferring parties had agreed on a general formula for a constitutional reform in Syria (a constitutional reform process of up to 18 months, followed by an early presidential election). However, the parties had failed to reach agreement either on the list of terrorist organizations, or on whether or not President Bashar al-Assad should be allowed to take place in the aforesaid presidential election.

Thus, the situation in Syria has remained deadlocked. It is likely that a decisive victory over 'Islamic State' cannot be achieved without having launched a major ground operation involving (as previously in Afghanistan and Iraq) about 100 personnel, properly armed, equipped and trained in modern warfare. However, it can be expected that such an operation would incur serious economic costs for any country involved therein, including the USA, Russia and the countries of Europe. Moreover, the most likely participants of such an operation (if it ever takes place) have so far failed to reach an agreement as to which organization (or organizations) should be the object thereof, thus creating the risk of clashes between the participants of the ground operation. Therefore, for now at least, all the countries involved in the Syrian conflict do not go beyond promises to intensify their aerial bombardment of terrorist positions in Syria.

As a result of the shooting down of the Russian bomber by a Turkish warplane, Russia has slammed Turkey with economic sanctions. Russia has imposed a ban on the sale of Turkish holiday packages to Russians by Russian travel agencies. This ban will certainly deliver a heavy blow to the Russian tourist industry, which had already been shaken by the Egypt flight ban. It should be added that, before the previously mentioned fateful incident, Russian tour operators had desperately hoped that Turkish resorts could well replace popular Egyptian destinations for most of their clients. Russia will suspend the visa-free regime with Turkey from 1 January 2016. President Putin has instructed the RF Government 'to define a list of goods and services to which the economic measures [against Turkey] do not apply'. Thus, the existing construction contracts will remain valid, and the Turkish personnel recruited under them will not be affected. Russia has imposed a ban on the import of Turkish meat, poultry, tomatoes, onions, cabbage, cucumbers, oranges, tangerines, apples and other vegetables and fruits. Previously, the share of food imports from Turkey amounted to about $4 \%$ of Russia's total food imports. However, the share of some food imports from Turkey, especially that of tomatoes and citrus fruits was much higher. Also, Russia has suspended the Turkish Stream gas pipeline project, although it should be noted that the two sides had not finalized the deal, and the corresponding intergovernmental agreement had not been signed before disaster struck. The future of Turkey's Akkuyu nuclear power plant project (previously it was planned that the project would be financed by a Russian state loan).

It should be said that Russia has a huge trade surplus with Turkey. Thus, in 2015 , Russia has already exported, to Turkey, goods to the value of $\$ 16 \mathrm{bn}$ 
(in the main natural gas, oil and petroleum products), having imported, from Turkey, goods to the value of $\$ 6 \mathrm{bn}$ (in the main engineering products, agricultural products, and light industry products). So far, Turkey has not imposed on Russia any retaliatory sanctions. Most likely, Ankara will try to reduce purchase of natural gas from Russia (Turkey has two LNG regasification terminals). Also, some problems have already emerged with the passage of Russian naval and merchant ships through the Bosporus Strait.

November 2015 saw a sharp deterioration of the situation on the RussiaUkraine border. Ukrainian power lines to the Crimea were sabotaged, some of their pylons being blown up. Repair work on the sabotaged lines began after long delay, and electricity supplies to the Crimea have not been resumed as yet. Apparently, having repaired and put into operation yet another reactor of the Rivne nuclear power plant, Ukraine hopes that no further purchases of electricity from Russia will be necessary, and that it has enough natural gas in its storage facilities to get through the winter. In response, Russia and the authorities of the self-proclaimed Donetsk and Lugansk People's Republics have suspended coal supplies to Ukraine. The situation on the front lines in eastern Ukraine is rapidly deteriorating: the number of occurrences of smallarms fire and shelling incidents has considerably increased, although it cannot be said that major-scale hostilities have already resumed.

In November, one of the most noteworthy events on the Russian domestic scene was the launch of Platon, a new federal highway system that imposes tolls on vehicles weighing more than 12 metric tons. The system is operated by the LLC RT-Invest Transportation Systems, in part owned by the State, via the state company Rostekhnologii [Russian Technologies], and in part by Igor Rotenberg, son of the well known Russian entrepreneur Arkady Rotenberg. The Platon system is designed to impose additional tolls on heavy cargo trucks. The system was put in operation on 15 November and immediately caused widespread condemnation and indignation among truckers. Their protests forced the RF Government to make a number of concessions mitigating the system: thus, the authorities proposed a considerable reduction in fines and postponed the beginning of their exaction until May 2016. The government also abolished the provision that all the charges under the Platon system should be paid in advance. Nevertheless, both the truckers and the cargo transportation businesses continue to bombard the government with their demands that the Platon system should be further mitigated or, better still, abolished. They point it out that the new tolls will coexist with the current transport tax and fuel excise taxes. It is estimated that the new tolls will increase the transportations costs of Russia's big rigs by $15 \%$ to $20 \%$ or even more. Whether or not this conflict will be resolved in favour of the protestors apparently depends on their ability to persevere in their demands.

In November 2015, the RF State Duma passed in second reading the draft federal budget for 2016, which had remained practically unchanged since its first reading. Thus, the RF Government has so far managed to keep political pressure groups under its control. However, it is likely that it will come under increased pressure from defence lobbyists due to the ever worsening international situation. It should be noted, however, that even at its current level defense spending represents a very heavy burden on the federal budget, accounting, together with expenditures on law-enforcement activities, for almost one-third of total federal budget expenditure. 